\title{
Causes of early Holocene desertification in arid central Asia
}

\author{
Liya Jin · Fahu Chen · Carrie Morrill • \\ Bette L. Otto-Bliesner • Nan Rosenbloom
}

Received: 11 November 2010/Accepted: 22 April 2011/Published online: 12 May 2011

(C) The Author(s) 2011. This article is published with open access at Springerlink.com

\begin{abstract}
Paleoclimate records of effective moisture (precipitation minus evaporation, or $P-E$ ) show a dry (low effective moisture) period in mid-latitude arid/semi-arid central Asia during the early Holocene $(11,000-8,000$ years ago) relative to the middle and late Holocene, in contrast to evidence for greater-than-present precipitation at the same time in the south and east Asian monsoonal areas. To investigate the spatial differences in climate response over mid-latitude central Asia and monsoonal Asia we conducted a series of simulations with the Community Climate System Model version 3 coupled climate model for the early, middle and late Holocene. The simulations test the climatic impact of all important forcings for the early Holocene, including changes in orbital parameters, the presence of the remnant Laurentide ice sheet and deglacial
\end{abstract}

\section{Jin $(\varangle) \cdot$ F. Chen}

Key Laboratory of Western China's Environmental System, Lanzhou University, Lanzhou 730000, Gansu, China

e-mail: jinly@1zu.edu.cn

\section{Jin}

Institute of Geosciences, University of Kiel,

Ludewig-Meyn-Str. 10, 24118 Kiel, Germany

C. Morrill

Cooperative Institute for Research in Environmental Sciences,

University of Colorado, Boulder, CO 80309, USA

C. Morrill

Paleoclimatology Branch, NOAA's National Climatic Data

Center, Boulder, CO 80305, USA

B. L. Otto-Bliesner · N. Rosenbloom

Climate and Global Dynamics Division, National Center

for Atmospheric Research, Boulder, CO 80305, USA freshening of the North Atlantic. Model results clearly show the early Holocene patterns indicated by proxy records, including both the decreased effective moisture in arid central Asia, which occurs in the model primarily during the winter months, and the increase in summer monsoon precipitation in south and east Asia. The model results suggest that dry conditions in the early Holocene in central Asia are closely related to decreased water vapor advection due to reduced westerly wind speed and less evaporation upstream from the Mediterranean, Black, and Caspian Seas in boreal winter. As an extra forcing to the early Holocene climate system, the Laurentide ice sheet and meltwater fluxes have a substantial cooling effect over high latitudes, especially just over and downstream of the ice sheets, but contribute only to a small degree to the early Holocene aridity in central Asia. Instead, most of the effective moisture signal can be explained by orbital forcing decreasing the early Holocene latitudinal temperature gradient and wintertime surface temperature. We find little evidence for regional subsidence related to a stronger summer Asian monsoon in forcing early Holocene aridity in central Asia, as has been previously hypothesized.

Keywords Early Holocene - Desertification - Arid central Asia $\cdot$ Climate model $\cdot$ Orbital forcing

\section{Introduction}

Over the Eurasian continent, large arid/semi-arid regions exist in the mid-latitudes from Turkey to the middle reaches of the Yellow River in China. The dry climate across this vast region is a result of the area's extreme continentality and its topography (Broccoli and Manabe 1992). Throughout the year, the western and northwestern 
plains of central Asia are open to cold northerly and northwesterly inflows as well as to moist westerly Atlantic air masses. The latter as well as moisture from inland seas and lakes (e.g. Caspian Sea) provide major water vapor transport into this region (Böhner 2006). In contrast, the precipitation in eastern and southern Asia is closely related to the Asian summer monsoon climate with water vapor transport from the Indian and Pacific Oceans.

Fluctuations in water resources in central Asia have important implications for fragile ecosystems and human activities in this region, and there is evidence for substantial variability through the Holocene. Most significantly, widespread and severe desertification occurred in central Asia during the early Holocene prior to 8,000 years ago as evidenced in recent years by paleosol stratigraphies, pollen and diatom assemblages, sedimentology, lake levels and geochemistry (Chen et al. 2008; Feng et al. 2006; Herzschuh 2006; Huang et al. 2009). The cause of this extreme aridity has been obscured, however, by the complex interplay of competing factors controlling regional climate in central Asia, an area that might have been influenced by the mid-latitude westerlies, low-latitude Asian summer monsoon as well as regional circulations related to the orography of the Tibetan Plateau.

Two competing hypotheses have been proposed to explain early Holocene aridity. First, Chen et al. (2008) found a similar pattern during the Holocene between moisture changes in arid central Asia based on lake sediment records and temperature changes from the North Atlantic (Kaplan and Wolfe 2006) and the GRIP ice-core (Dahl-Jensen et al. 1998), namely that dry climate conditions in central Asia correspond to low North Atlantic and Greenland temperatures before $8 \mathrm{ka}$ BP. This implies a possible tele-connection in climate change between North Atlantic and central Asia. With the inception of Holocene, the temperature in mid- and high latitudes of Northern Hemisphere increased rapidly from glacial values. However, the last remnant of the Laurentide Ice Sheet (LIS) was still fairly extensive in the early Holocene (Peltier 2004) until the end of deglaciation at $\sim 7 \mathrm{ka} \mathrm{BP}$ (Carlson et al. 2008). Despite high summer insolation during the early Holocene, the LIS likely played a significant role in keeping the North Atlantic relatively cool compared to the middle and late Holocene by reducing surface albedo and by meltwater-induced slowing of the Atlantic Meridional Overturning Circulation (Clark et al. 1999). Cool temperatures in the North Atlantic forced by the LIS could have led to low water vapor transport in the westerlies and dry conditions in central Asia.

A second hypothesis links moisture in central Asia with the strength of the Asian monsoon through regional climate dynamics. In monsoonal Asia, multi-proxy data from cave deposits (e.g., Fleitmann et al. 2003; Shao et al. 2006), peats (Hong et al. 2005), lake sediments (Lister et al. 1991; Gu et al. 1993; Hodell et al. 1999; Morrill et al. 2003; Xiao et al. 2004; Shen et al. 2005) and marine sediments (Wang et al. 1999; Gupta et al. 2003) suggest that the Indian and East Asian summer monsoons were enhanced during the early to mid-Holocene. Enhanced diabatic heating in the core region of the strengthened summer monsoon could result in increased subsidence in drylands to the north along the desert margin (Broccoli and Manabe 1992; Masson et al. 2009).

Here we present an analysis of the causes of widespread desertification in central Asia in the early Holocene relative to conditions in the middle and late Holocene. The analysis is based on a series of sensitivity experiments using a coupled climate model, the Community Climate System Model, version 3 (CCSM3.0). The outline of the paper is as follows. Section 2 briefly describes the model and the experimental setup. Section 3 summarizes paleoclimate proxy data from the region for comparison with model results. Section 4 displays the model results with a comparison of simulations of the early, middle and late Holocene. A summary and the concluding remarks are presented in Sect. 5.

\section{Methods}

\subsection{Model description}

The coupled climate simulations discussed in this paper are performed with the CCSM3.0, which is a global, coupled ocean-atmosphere-sea ice-land surface climate model. The atmospheric model is the Community Atmospheric Model Version 3 (CAM3), which is a threedimensional primitive equation model solved with the spectral method in the horizontal (Collins et al. 2006). The ocean model is an implementation of the Parallel Ocean Program (POP) and is a three-dimensional primitive equation model in spherical polar coordinates with dipole grid and vertical $\mathrm{z}$ coordinate (Gent et al. 2006). The sea ice model is a dynamic-thermodynamic model, which includes a sub-grid-scale ice thickness parameterization and elastic viscous-plastic rheology (Briegleb et al. 2004). The land model includes a river routing scheme and specified land cover and plant function types (Dickinson et al. 2006). Model resolutions used in this study are a T42 atmosphere-land grid (an equivalent grid spacing approximately $2.8^{\circ}$ in latitude and longitude) coupled with the $\times 1$ ocean-sea ice grid (a nominal grid spacing of approximately $1^{\circ}$ in latitude and longitude with greater resolution in the Tropics and North Atlantic) (OttoBliesner et al. 2006). More model details can be found in Collins et al. (2006). 


\subsection{Experimental setup}

We ran equilibrium simulations for three time slices using the CCSM3.0: the early Holocene (8,500 years before present (BP), Exp_8.5 ka), the mid-Holocene $(6,000$ years BP, Exp_6 ka) and the pre-Industrial (1800 A.D., PI). The PI experiment was previously described in detail by Otto-Bliesner et al. (2006) and followed the protocols established by PMIP-2 (http://www-lsce.cea.fr/pmip2). Exp_8.5 ka and Exp_6 ka were branched from the PI experiment, using appropriate orbital forcings and trace gas concentrations (Table 1).

To test the impact of residual ice-sheet over the North America (Laurentide Ice Sheet, or LIS) on early Holocene climate, an extended sensitivity experiment (Exp_8.5ka $\mathrm{ICE}_{\mathrm{ICE}}$ ) added the LIS as reconstructed for 8.5 ka by Peltier (2004) over North America. To consider the effects of the LIS background meltwater flux during the early Holocene, we performed a further experiment extended from Exp_8.5ka ICE $\left(\right.$ Exp_8.5ka $\left.\mathrm{keLTICE}_{\text {M }}\right)$ with freshwater flux at the mouth of the St. Lawrence River increased by 0.05 Sverdrups $\left(1 \mathrm{~Sv}=10^{6} \mathrm{~m}^{3} / \mathrm{s}\right.$, Table 1$)$. The magnitude of this flux was taken from Licciardi et al. (1999) and was based on reconstructions of the mass balance of the Laurentide Ice Sheet and river routing through time. The sea level change was not considered in any experiment because it is a relatively small forcing.

We make two sets of comparisons between the model simulations. First, we compare our 8.5 ka experiments with the PI and Exp_6 ka simulations to verify that the model accurately represents the Holocene evolution of effective moisture in arid Central Asia and to test the two competing hypotheses for the cause of this evolution. Second, we compare the $8.5 \mathrm{ka}$ experiments among themselves to gauge the relative influence of orbital forcing and deglacial boundary conditions in causing effective moisture changes. All model data analyzed in this paper are from relatively long simulations with 100 years averaged for monthly ensembles except one simulation, Exp_8.5 ka. For Exp_8.5 ka, we use 50 years simulation since no additional years were available. We also correct all model output for the difference between the fixed-day and the fixed-angular calendars (Chen et al. 2010), although this has no significant impact on our conclusions given relatively low eccentricity values during the Holocene.

Comparison of the CCSM3.0 PI simulation with proxybased climate reconstructions of the preindustrial period (Otto-Bliesner et al. 2006) and with instrumental records of the early industrial period indicates this model does a reasonable job simulating climate in Eurasia. In Fig. 1, which shows a comparison of model output with observations of annual mean precipitation (Fig. 1a) and surface temperature (Fig. 1b) for 1901-1930 from the Climate Research Unit TS 2.1 climate dataset (Mitchell and Jones 2005), the spatial distribution and absolute values of simulated annual mean precipitation (Fig. 1c) and surface temperature (Fig. 1d) over the Eurasian continent for PI are smoothed relative to observations yet still realistic. The same holds true for seasonal patterns (not shown).

\subsection{Moisture budget analysis}

To identify the dynamical and thermodynamical factors responsible for changes in balance of precipitation and evaporation $(P-E)$ between simulations we will evaluate the moisture budget equation for a column in the atmosphere (Seager et al. 2010):

$$
\begin{aligned}
P-E= & -\frac{1}{\rho_{w} g} \int_{0}^{p_{s}}(\overline{\mathbf{u}} \cdot \nabla \bar{q}+\bar{q} \nabla \cdot \overline{\mathbf{u}}) d p \\
& -\frac{1}{\rho_{w} g} \int_{0}^{p_{s}} \nabla \cdot\left(\overline{\overline{\mathbf{u}}^{\prime} \mathbf{q}^{\prime}}\right) d p-S
\end{aligned}
$$

Here, overbars indicate monthly means and primes departures from the monthly mean, $\rho_{w}, q, g, p$ and $p_{s}$ represent the density of water, specific humidity, acceleration due to gravity, pressure, pressure at ground surface, respectively, $\mathbf{u}$ is the horizontal wind vector and $S$ indicates terms involving surface quantities as defined by Seager et al.

Table 1 Boundary conditions used in CCSM3.0 simulations

\begin{tabular}{llllll}
\hline & PI & Exp_6 ka & Exp_8.5 ka & Exp_8.5 ka ICE & Exp_8.5 ka MELTICE \\
\hline Eccentricity & 0.016724 & 0.018682 & 0.019199 & Same as Exp_8.5 ka & Same as Exp_8.5 ka \\
Obliquity $\left(^{\circ}\right)$ & 23.45 & 24.10 & 24.22 & Same as Exp_8.5 ka & Same as Exp_8.5 ka \\
Longitude of perihelion $\left(^{\circ}\right)$ & 102.04 & 0.87 & 319.50 & Same as Exp_8.5 ka & Same as Exp_8.5 ka \\
$\mathrm{CO}_{2}(\mathrm{ppm})$ & 280 & 280 & 260 & Same as Exp_8.5 ka & Same as Exp_8.5 ka \\
$\mathrm{CH}_{4}(\mathrm{ppb})$ & 760 & 650 & 660 & Same as Exp_8.5 ka & Same as Exp_8.5 ka \\
$\mathrm{N}_{2} \mathrm{O}(\mathrm{ppb})$ & 270 & 270 & 260 & Same as Exp_8.5 ka & Same as Exp_8.5 ka \\
Laurentide Ice Sheet & None & None & None & Peltier (2004) & Peltier (2004) \\
St. Lawrence meltwater flux & None & None & None & None & 0.05 Sverdrups \\
\hline
\end{tabular}



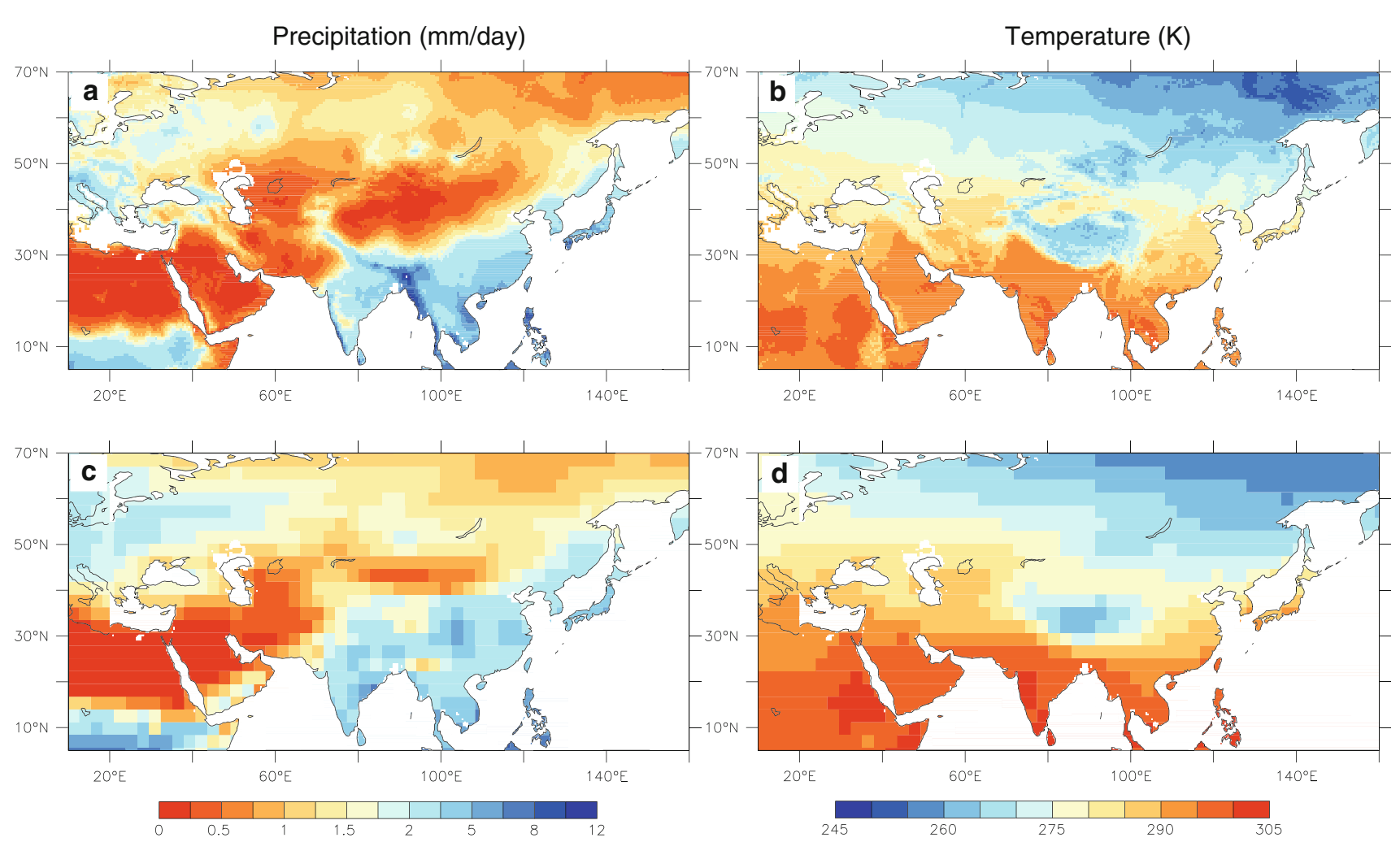

Fig. 1 Comparison of annual mean precipitation and annual mean surface temperature from the Climate Research Unit TS 2.1 dataset for 1901-1930 (a, b) and CCSM3 pre-industrial simulation $(\mathbf{c}, \mathbf{d})$

(2010). The first integral on the right hand side describes moisture convergence by the mean flow, which consists of terms representing the mean flow acting upon the specific humidity gradient (hereafter called the advection term) and the mass convergence acting upon the mean specific humidity (hereafter called the mass convergence term). The second integral describes moisture convergence by transient eddies. Since model output is available only as monthly means, we cannot explicitly calculate the transient eddy and surface terms. By assuming no tendency in precipitable water through the atmospheric column, which is a reasonable assumption for long-term averages from an equilibrium simulation, we instead approximate these transient eddy and surface terms as the residual of $P-E$ and moisture convergence by the mean flow.

The relative importance of changes in specific humidity and wind vectors for the advection term or the mass convergence term can be further examined, as described here using the advection term as an example. The advection term is dependent on the mean flow $\overline{\mathbf{u}}$ and the specific humidity gradient $\nabla \bar{q}$ (Eq. 1). For the mid-latitude regions of Eurasia, the former can be thought of as the strength of the westerlies and the latter is related to the amount of evaporation upstream from the North Atlantic Ocean and Mediterranean, Black and Caspian Seas. To determine how these two components, termed the thermodynamic (Eq. 2) and dynamic (Eq. 3) contributors to advection, respectively, contribute to the overall change in advection, the following two equations are used (Seager et al. 2010):

$\delta A d v_{T H}=-\frac{1}{\rho_{w} g} \int_{0}^{p_{s}} \overline{\mathbf{u}}_{C} \cdot \nabla \delta \bar{q} d p$

$\delta A d v_{D}=-\frac{1}{\rho_{w} g} \int_{0}^{p_{s}} \delta \overline{\mathbf{u}} \cdot \nabla \bar{q}_{C} d p$

where the subscripted $T H$ and $D$ indicate thermodynamic and dynamic terms respectively, the subscripted $C$ indicates values from a control simulation and $\delta$ indicates the difference between an $8.5 \mathrm{ka}$ BP simulation experiment and a control simulation (in our usage, either PI or Exp_6 ka).

\section{Summary of available proxy data}

Before considering model results, it is important to review and summarize the large-scale patterns in effective moisture since the early Holocene that we expect the model to simulate. The model must be able to reproduce these patterns if it is to be useful in testing hypotheses about their 
causes. Many proxies including pollen and diatom assemblages, sediment lithology, lake levels, and geochemistry data have been used to infer Holocene climate changes in the vast area of central Asia and monsoonal Asia. To review the work of Chen et al. (2008), who considered sediment records of eight lakes with reliable chronologies, moisture changes in mid-latitude central Asia show that a drier-than-present climate prevailed in the early Holocene before $8 \mathrm{ka} \mathrm{BP}$ and wettest conditions with the highest lake levels or densest vegetation cover are in the mid-Holocene around 8-4 ka BP (Fig. 2).

In contrast to the moisture history of central Asia, the effective moisture $(P-E)$ in monsoonal Asia as inferred from speleothem records indicates a stronger summer monsoon (more precipitation) in the early to mid-Holocene (Yuan et al. 2004; Wang et al. 2005; Shao et al. 2006; Fleitmann et al. 2003, 2007). Similarly, Herzschuh (2006) finds, based on a multi-proxy synthesis of 75 records, that the Indian Monsoon area experienced wettest conditions during the early Holocene (10.9-7.0 ka BP) and the South East (SE) Asian Monsoon area shows rather wet conditions from the early until the middle of the later Holocene with highest moisture during the early mid-Holocene (8.3-5.5 ka $\mathrm{BP}$ ). While our study is not focused on monsoonal Asia per se, it is important to ensure that the Holocene evolution of monsoon strength is accurately simulated since this may affect moisture patterns in arid Central Asia through regional climate dynamics (Masson et al. 2009).

\section{Model results and discussion}

\subsection{Surface temperature}

Orbitally-induced changes in the seasonal distribution of insolation (Fig. 3) are clearly reflected by surface temperature change between the simulations. The zonallyaveraged insolation at $8.5 \mathrm{ka} \mathrm{BP}$ was more than $30 \mathrm{~W} / \mathrm{m}^{2}$ greater compared to PI (Fig. 3c) and $5-10 \mathrm{~W} / \mathrm{m}^{2}$ greater compared to $6 \mathrm{ka}$ BP (Fig. 3d) during boreal summer (June-July-August, or JJA) in the Northern Hemisphere. Corresponding to the changes in seasonal insolation, simulated summer (JJA) surface temperature in Exp_8.5 ka relative to PI is warmer across most of the Northern Hemisphere with maximum warming, in excess of $2 \mathrm{~K}$, extending from $20^{\circ} \mathrm{N}$ over the Sahara to $65^{\circ} \mathrm{N}$ over central Russia (Fig. 4b). Interestingly, surface temperatures over south Asia are cooler in Exp_8.5 ka than PI (Fig. 4b), which has been attributed to increased monsoon cloud cover in the early Holocene ( $\mathrm{Li}$ and Morrill 2010). In boreal winter (December-January-February, or DJF) the cooling over most of Eurasia is more than $3 \mathrm{~K}$ (Fig. 4a).

In experiment Exp_8.5 ka $\mathrm{ICE}_{\mathrm{ICE}}$, the presence of the remnant LIS has a significant cooling effect on the climate over northeastern North America and over Greenland in all seasons, where the surface temperature decreased by as much as $6 \mathrm{~K}$ in DJF (Fig. 4c) and $3 \mathrm{~K}$ in JJA (Fig. 4c) compared to both Exp_8.5 ka and PI, counteracting orbital forcing. Cooling is further intensified over the northern North Atlantic (between $50^{\circ}$ and $60^{\circ} \mathrm{N}$ ) by up to $2 \mathrm{~K}$ in DJF in Exp_8.5 ka MeLtice compared to Exp_8.5 ka ICE (not shown) due to a slowdown of the Atlantic Meridional Overturning Circulation from $\sim 19$ to $\sim 17 \mathrm{~Sv}$. However,

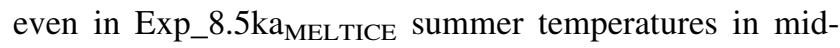
latitude Eurasia were still warmer than those at PI and 6 ka (Fig. 4b, f, h). These results are in general agreement with a transient simulation for the Holocene using the ECBilt-CLIO-VECODE model in which the LIS had an important effect on surface temperature over the Eurasian continent between $45^{\circ}$ and $60^{\circ} \mathrm{N}$ but had no significant effect to the south of this area, suggesting that temperatures to the south of $45^{\circ} \mathrm{N}$ in Eurasian are controlled
Fig. 2 Temporal moisture changes as evidenced from paleo-lake sediment records in central Asia during the Holocene, revised from Chen et al. (2008). Numbers $1-8$ match those in Figs. 5, 8, and 9

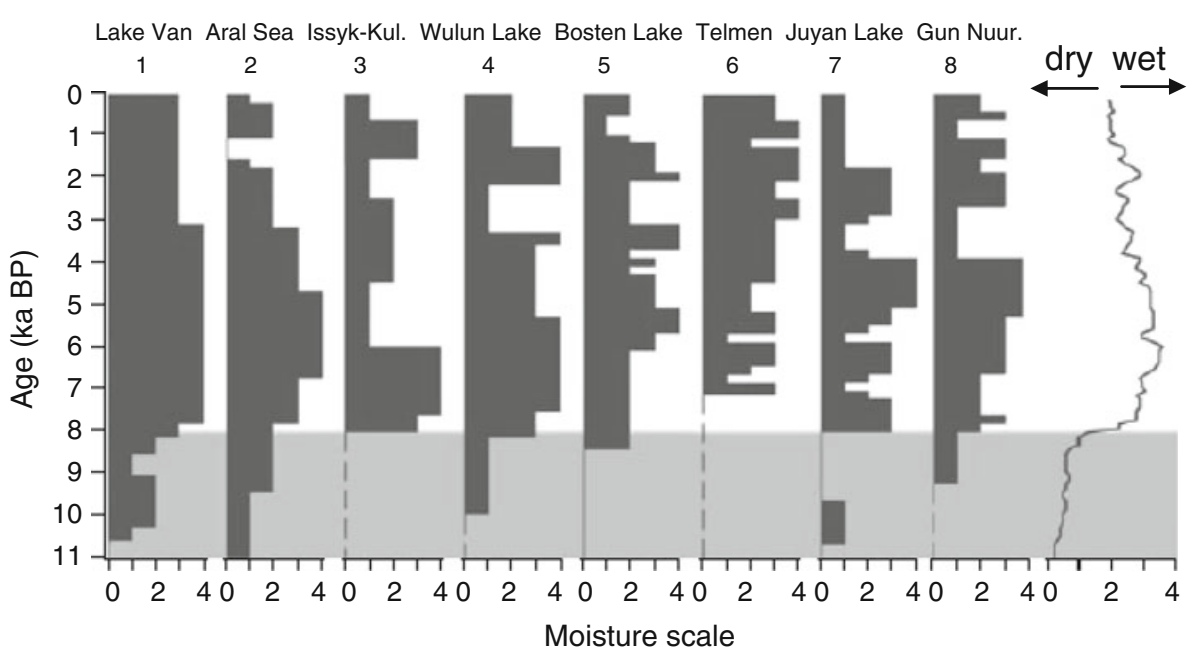



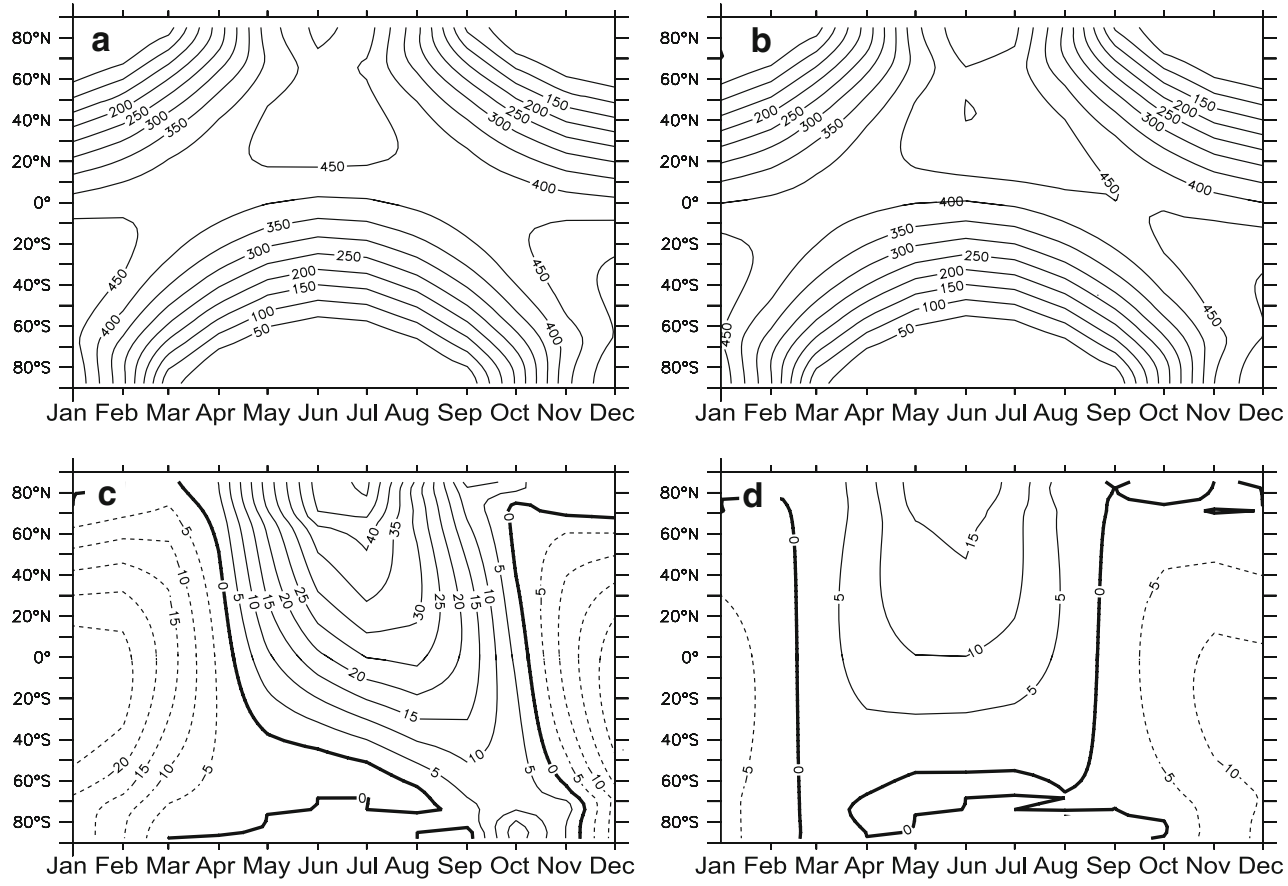

Fig. 3 Time versus latitude diagram of zonally-averaged differences in incoming solar radiation $\left(\mathrm{W} / \mathrm{m}^{2}\right)$ at the top of the atmosphere at a present day (PI) and b $8.5 \mathrm{ka} \mathrm{BP}$, as well as the differences, c $8.5 \mathrm{ka}$ BP minus PI and $\mathbf{d} 8.5 \mathrm{ka}$ BP minus $6.0 \mathrm{ka}$ BP

mainly by orbital forcing throughout the Holocene (Renssen et al. 2009).

\subsection{Precipitation and effective moisture $(P-E)$}

Figure 5 shows the annual mean changes in precipitation $(P)$ (Fig. 5a, c) and effective moisture $(P-E)$ (Fig. 5b, d) between Exp_8.5kameltice and Exp_6 ka and PI simulations. We chose to focus here on annual mean changes since the effective moisture changes shown in Fig. 2 are largely based on lake level indicators that integrate over the annual cycle. Comparisons using Exp_8.5 ka ICE and Exp_8.5ka look quite similar to those in Fig. 5 (not shown).

In general, the northern part of Eurasia (north of $45^{\circ} \mathrm{N}$ ), Taklimakan region and the Loess Plateau have less annualmean precipitation and $P-E$ (negative anomalies) in Exp_8.5ka MeLtice compared to Exp_6 ka (Fig. 5c, d) and PI (Fig. 5a, b), whereas the remainder of Eurasia has more (positive anomalies).

Averaging over the region of arid Central Asia in the vicinity of most of the proxy records shown in Fig. 2 (defined here as $45^{\circ}-55^{\circ} \mathrm{N}$ and $60^{\circ}-100^{\circ} \mathrm{E}$ ), annual precipitation, evaporation and $P-E$ are all lower, significant at the $95 \%$ level, in Exp_8.5ka Meltice compared to the Exp_6 ka and PI simulations (not shown). $P-E$ has negative anomalies since evaporation does not decrease quite as much as precipitation. There are no significant differences in annual $P-E$, which is the most relevant variable to compare with proxy indicators, for this region between Exp_8.5 $\mathrm{ka}_{\text {MELTICE }}$ and the other two $8.5 \mathrm{ka}$ simulations (not shown).

The seasonal contributions to the annual mean $P$ and $P-$ $E$ anomalies between Exp_8.5ka $\mathrm{keLTICE}_{\text {and }}$ the Exp_6 ka and PI simulations are regionally different. Positive anomalies result from changes in DJF (Mediterranean Sea), MAM (March-April-May) and SON (September-October-November) (areas south of the Black, Caspian and Aral Seas) or JJA (June-July-August) (Indian and eastern Asian monsoon regions, including the Tibetan Plateau) (not shown). As discussed in greater detail below, negative anomalies in arid central Asia mainly come about from changes in boreal winter climate.

The CCSM3.0 model results are generally consistent with the paleo-climate proxy data derived from central Asia (Fig. 2) as well as from the Indian and East Asian monsoon regions. The simulations show reduced moisture at $8.5 \mathrm{ka} \mathrm{BP}$ in arid central Asia compared to Exp_6 ka and PI, though the southern boundary of this region might be misplaced somewhat north. The model does not predict a small decrease in annual mean effective moisture between Exp_6 ka and PI as the proxy records indicate, but $\mathrm{Li}$ and Morrill (2010) show that changes in lake evaporation, which is not modeled by the CCSM3, may be important for this change. The model also does a good job in simulating greatest Indian monsoon precipitation at $8.5 \mathrm{ka}$ BP. Additionally, the simulated wetter conditions in western Eurasia for the early Holocene compared to PI 


\section{DJF}

Exp_8.5ka minus $\mathrm{PI}$

JJA
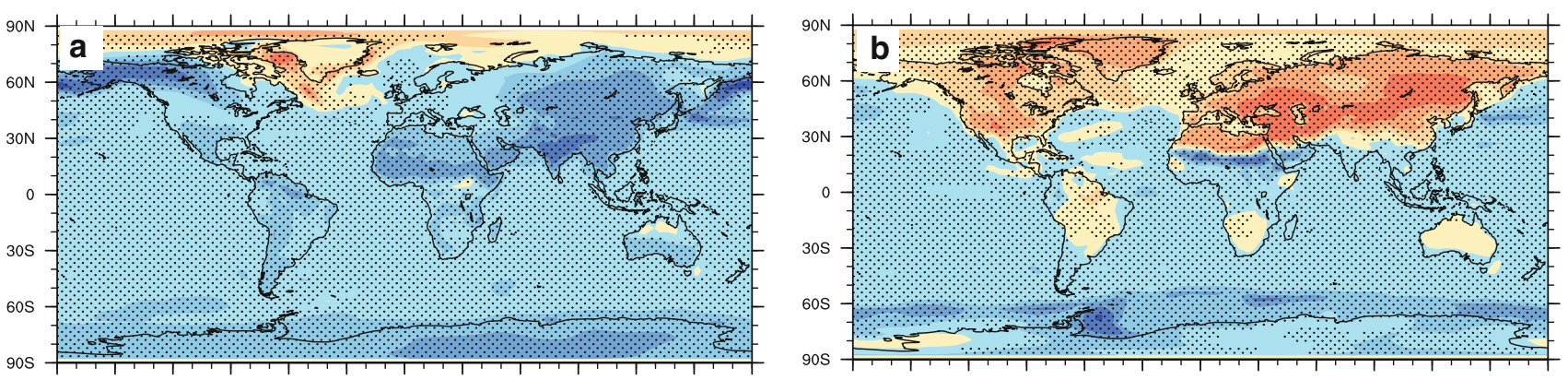

Exp_8.5ka ICE minus PI
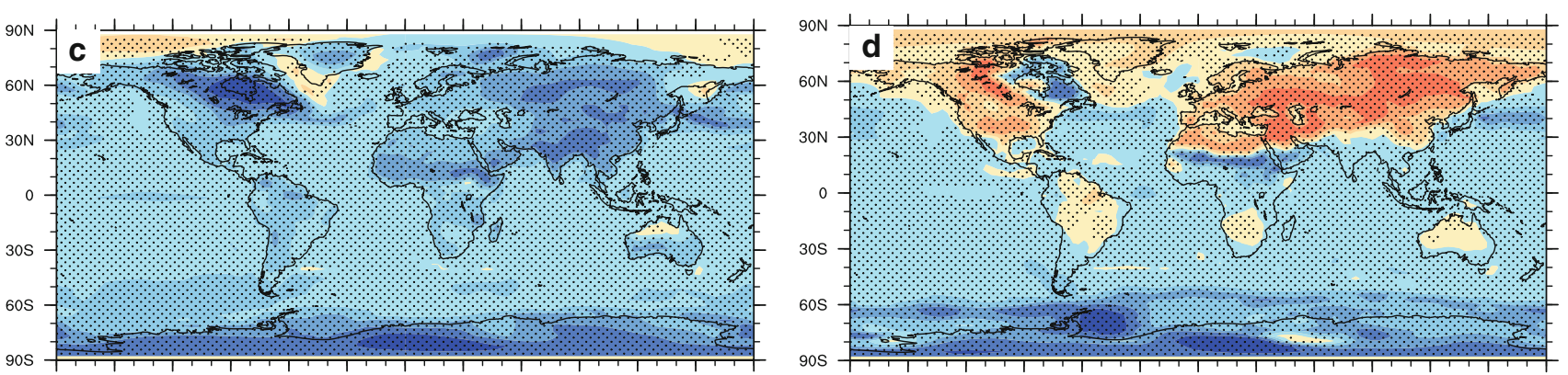

Exp_8.5ka MELTICE minus PI
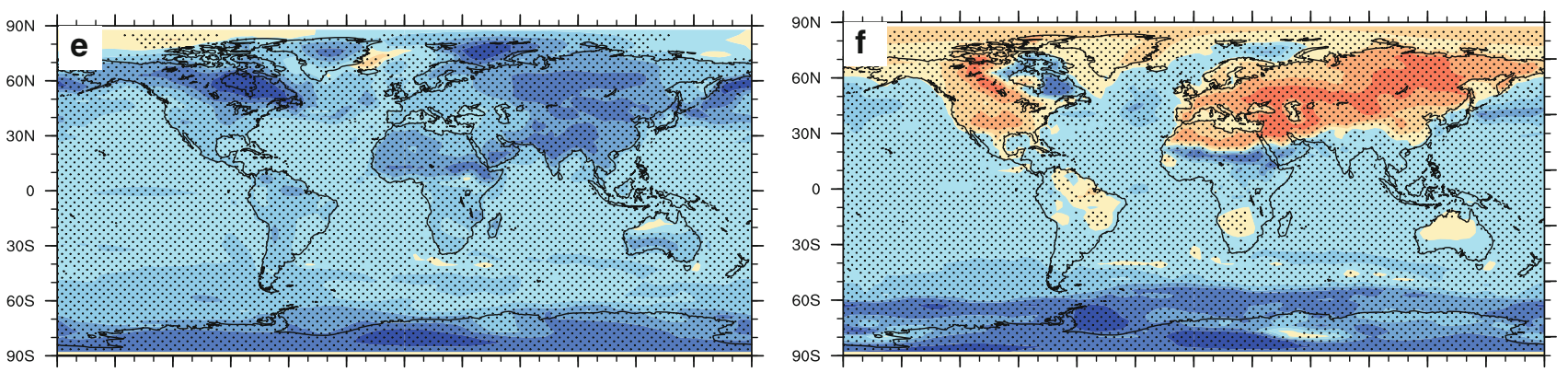

Exp_8.5ka meltice minus Exp_6ka
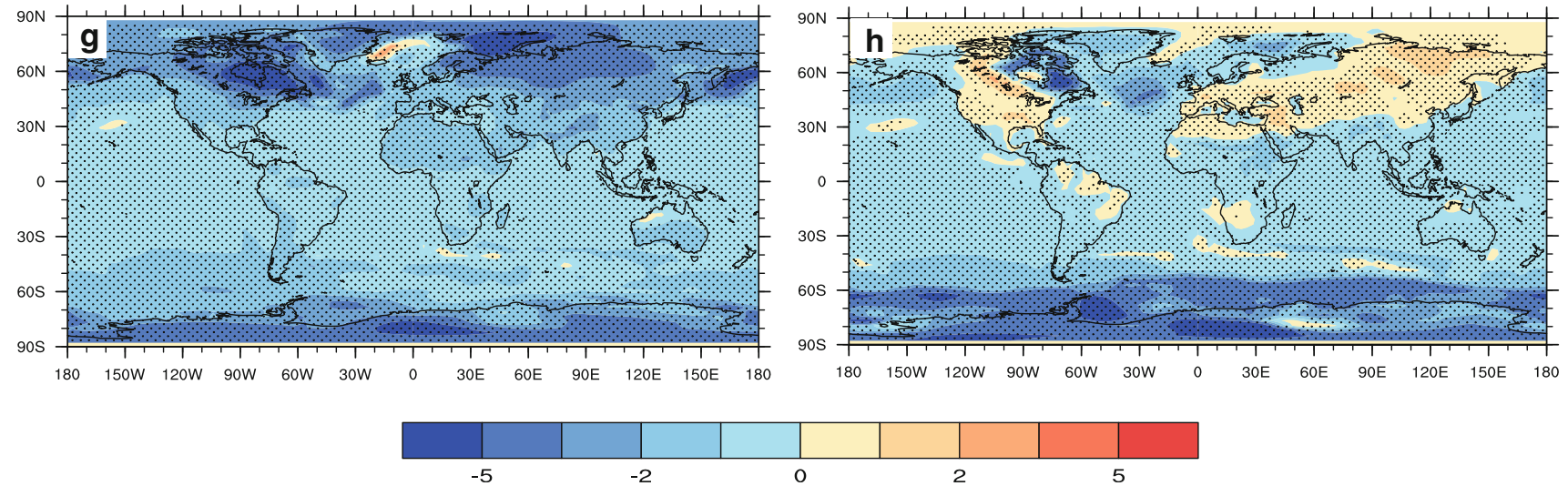

Fig. 4 Differences in surface temperature (K) between $8.5 \mathrm{ka}$ simulations and PI and 6.0 ka simulations for boreal winter (DJF) and summer (JJA). Stippling indicates differences that are significant at $95 \%$ level 

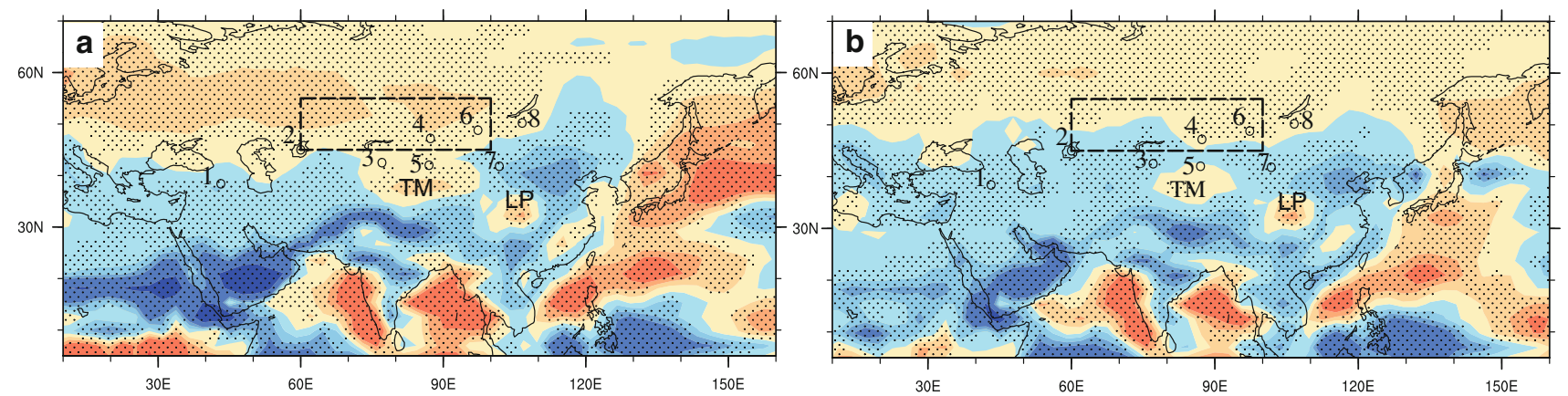

Exp_8.5ka MELTICE minus Exp_6ka

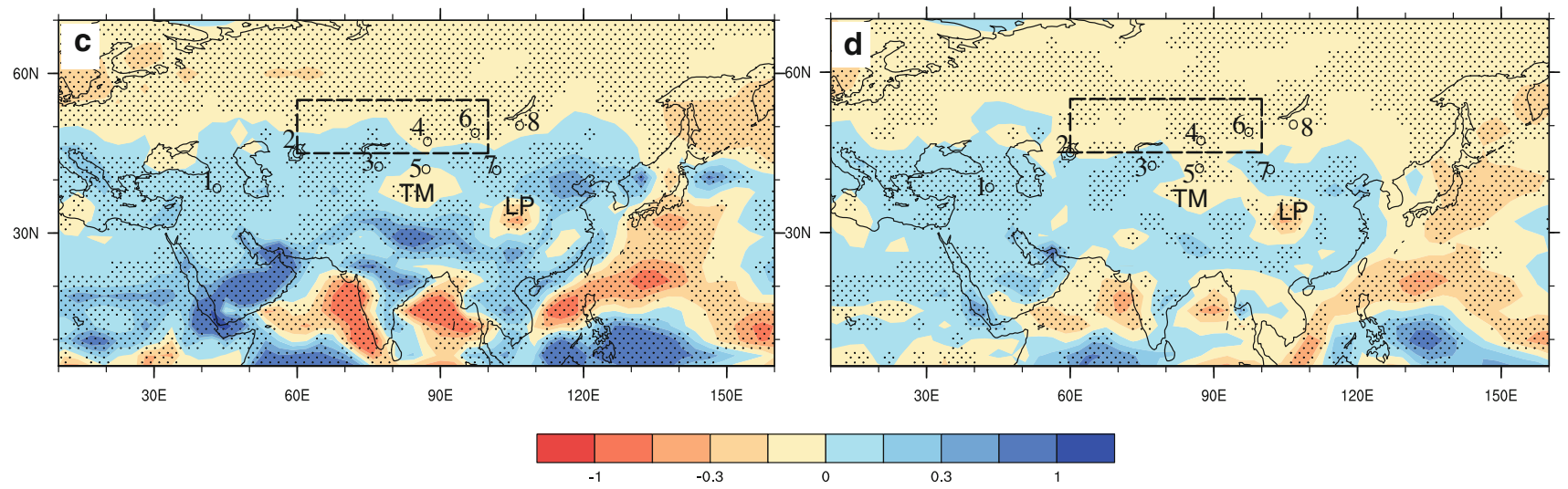

Fig. 5 Differences in precipitation (a, c, $\mathrm{mm} /$ day) and precipitation minus evaporation $(P-E)(\mathbf{b}, \mathbf{d}, \mathrm{mm} /$ day $)$. Abbreviations TM and LP show general location of Taklimakan Desert and Loess Plateau, respectively. The stippling shows differences that are statistically significant at $95 \%$ level using a Student's $t$ test. Open circles refer to paleoclimate proxy sites shown in Fig. 2 is in agreement with a crater-lake sequence from Eski Acrgol in central Turkey (Roberts et al. 2001), though a comparison with Lake Van in western Turkey (site \#1 in Fig. 5) (Wick et al. 2003) appears to be a mismatch. One weakness is in the modern East Asian summer monsoon transitional zone (around $41^{\circ}-42^{\circ} \mathrm{N}$, at $110^{\circ} \mathrm{E}$, Gao 1962), where the model simulates more summer precipitation and water vapor transport at $8.5 \mathrm{ka} \mathrm{BP}$ relative to PI than the proxy data indicate.

To examine the causes of decreased effective moisture in central Asia at $8.5 \mathrm{ka} \mathrm{BP}$ relative to the middle and late Holocene, we first determine the seasons that contribute most strongly to these anomalies. Looking at $P-E$ anomalies by month (Fig. 6), lower annual $P-E$ in the early Holocene experiments compared to PI is mostly due to anomalies in the winter months, with DJFM anomalies being most consistently prominent (Fig. 6a, c, e), while decreased annual $P-E$ compared to Exp_6 ka is due to anomalies from October to either March or April (Fig. 6b, $\mathrm{d}, \mathrm{f}$ ). In the following section, we will focus on the appropriate months for the analysis of the atmospheric moisture budget.

\subsection{Moisture budget calculations}

Using Eq. 1, the changes in the mean flow and the residual (transient eddies plus surface terms) that contribute to the changes in $P-E$ can be evaluated. We find that changes in $P-E$ between any of the $8.5 \mathrm{ka}$ experiments and PI are explained by changes in the mean flow, rather than by the residual terms (Table 2). More specifically, it is a reduction in the advection term rather than the mass convergence term that causes the reduction in $P-E$ (Table 2). This is also true for the changes in $P-E$ between the $8.5 \mathrm{ka}$ experiments and Exp_6 ka (months October to March, Table 2).

Using Eqs. 2 and 3, the relative contributions of changes in thermodynamics (i.e., upstream evaporation) and dynamics (i.e., strength of the westerlies) are considered for the overall changes in advection (Table 2). We find that, for comparisons with PI and Exp_6 ka, both dynamic and thermodynamic processes contributed to advection changes in similar amounts. (Note that in Table 2, the sum of the dynamic and thermodynamic contributions does not need to equal the advection term since Eqs. 2 and 3 are not 
Fig. 6 Differences in monthly mean precipitation-evaporation $(P-E)$ averaged for the region of central Asia $\left(45^{\circ}-55^{\circ} \mathrm{N}, 60^{\circ}-\right.$ $\left.100^{\circ} \mathrm{E}\right)$ between simulations. Error bars show $95 \%$ confidence interval. By definition, confidence intervals that do not overlap the zeroanomaly line indicate differences that are statisticallysignificant at the $95 \%$ level using a Student's $t$ test
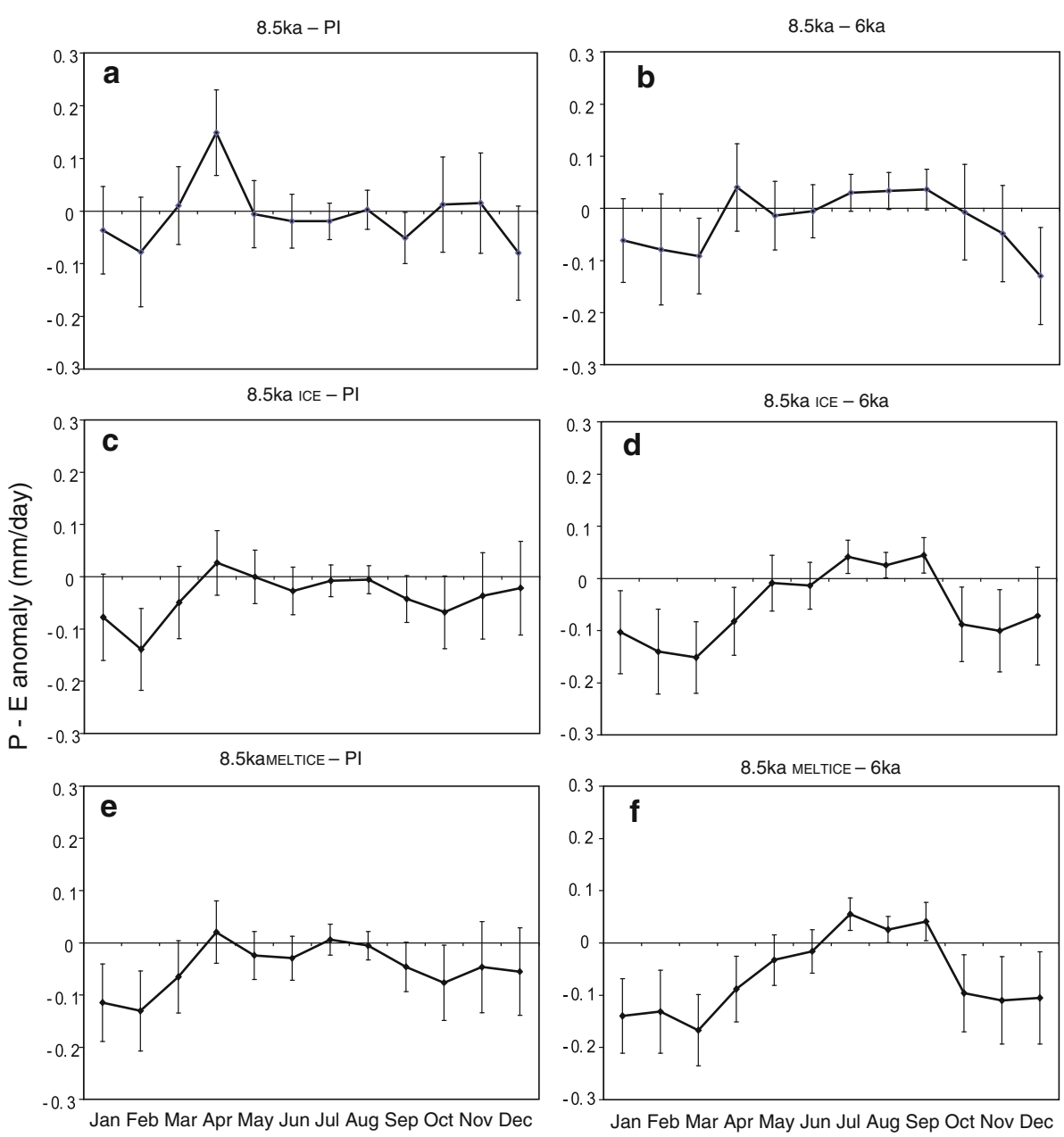

Table 2 Changes in winter moisture budget components over arid central Asia $\left(45^{\circ}-55^{\circ} \mathrm{N}, 60^{\circ}-100^{\circ} \mathrm{E}\right)(\mathrm{mm} / \mathrm{day})$

\begin{tabular}{|c|c|c|c|c|c|c|}
\hline & $\begin{array}{l}\text { Exp_8.5 } \\
\text { ka } a_{\text {MELTICE }}-\mathrm{PI}\end{array}$ & $\begin{array}{l}\text { Exp_8.5 } \\
\text { ka ICE-PI }\end{array}$ & $\begin{array}{l}\text { Exp_8.5 } \\
\mathrm{ka}-\mathrm{PI}\end{array}$ & $\begin{array}{l}\text { Exp_8.5ka } \mathrm{kELTICE}- \\
\text { Exp_6 } \mathrm{ka}\end{array}$ & $\begin{array}{l}\text { Exp_8.5ka }{ }_{I C E}- \\
\text { Exp_6 ka }\end{array}$ & $\begin{array}{l}\text { Exp_8.5 ka- } \\
\text { Exp_6 ka }\end{array}$ \\
\hline Precipitation-Evaporation & -0.09 & -0.07 & -0.04 & -0.13 & -0.11 & -0.07 \\
\hline Precipitation & -0.17 & -0.14 & -0.11 & -0.17 & -0.15 & -0.10 \\
\hline Evaporation & -0.07 & -0.07 & -0.07 & -0.05 & -0.04 & -0.04 \\
\hline Moisture convergence by mean flow & -0.16 & -0.15 & -0.11 & -0.14 & -0.12 & -0.09 \\
\hline Advection term & -0.20 & -0.17 & -0.14 & -0.15 & -0.12 & -0.09 \\
\hline Mass convergence term & 0.04 & 0.02 & $\mathbf{0 . 0 3}$ & 0.02 & 0.01 & 0.01 \\
\hline Residual & 0.07 & 0.07 & 0.06 & 0.01 & 0.01 & 0.03 \\
\hline \multicolumn{7}{|l|}{ Contributions to advection } \\
\hline Thermodynamic & -0.09 & -0.07 & -0.06 & -0.10 & -0.08 & -0.06 \\
\hline Dynamic & -0.12 & -0.11 & -0.08 & -0.08 & -0.08 & -0.05 \\
\hline
\end{tabular}

Differences from PI are for DJFM and from $6 \mathrm{ka} \mathrm{BP}$ are for October-March (ONDJFM). Bold indicates a difference statistically significant at the $95 \%$ level using a Student's $t$ test. Statistical test are not performed on contributions to advection

a decomposition of the advection term. Nonetheless, values in Table 2 are useful for giving a sense of the direction and magnitude of dynamic and thermodynamic contributions.) Our method using the moisture budget approach does not separate changes in zonal advection from meridional advection. To determine the directionality of advection changes, we made an additional calculation integrating winter-averaged $\mathbf{u}^{*} \mathrm{q}$ through the atmospheric column and along the edges of the study region. We find that moisture convergence due to zonal water vapor transport decreased 
during the early Holocene relative to the PI. Conversely, moisture convergence due to the meridional water vapor transport increased slightly during the early Holocene relative to PI, though to a lesser degree. The interpretation, therefore, is that reduced early Holocene advection relative to the middle and late Holocene was caused by a reduction in the strength of the westerlies along with a reduction in evaporation upstream.

The strength of the westerlies decreased significantly during boreal winter between $40^{\circ}$ and $60^{\circ} \mathrm{N}$ at $8.5 \mathrm{ka} \mathrm{BP}$ relative to PI (Fig. 7d, f, h) and 6 ka BP (Fig. 7j), which resulted from the decreased latitudinal temperature gradient between $40^{\circ} \mathrm{N}$ and the North Pole according to the thermal wind argument (Fig. 7c, e, g, i). This weakening of the latitudinal temperature gradient, represented by greater cooling at lower latitudes than at higher latitudes in the early Holocene relative to the middle and late Holocene, is predicted by the latitudinal distribution of orbitally-forced insolation changes (Fig. 3c, d). The latitudinal temperature gradient is reduced somewhat further in the presence of the LIS and meltwater flux (Fig. 7e, g compared to Fig. 7c), yet the weakening of the winter westerlies is quantitatively similar in all three $8.5 \mathrm{ka}$ BP model experiments (Fig. 7d, $\mathrm{f}, \mathrm{h}$ ), indicating that orbital forcing is the primary cause of the anomalies. Weakening of the westerlies is smaller from the early to middle Holocene (Fig. 7d, f, h) than from the early to late Holocene (Fig. 7j). This can be explained by smaller insolation changes (Fig. 2c, d).

The thermodynamics contribution $\left(\delta A d v_{T H}\right)$ to the negative anomalies in advection in the early Holocene compared to the middle and late Holocene results from lower evaporation upstream from the eastern Mediterranean, Black and Caspian Seas due to lower winter temperatures over these areas (Figs. 4a, c, e, g, 8). Decreased evaporation in the North Atlantic in Exp_8.5ka $\mathrm{kaltice}_{\text {Melative to }}$ Exp_6 ka and PI (Fig. 8c, d) might also contribute, but large areas of increased evaporation in the North Atlantic in the other $8.5 \mathrm{ka}$ simulations relative to PI (Fig. 8a, b) make it unlikely to be the main source of changes in $P-E$ in central Asia via advection.

\subsection{Effect of subsidence}

A dynamic link between enhanced upward flow in the Asian monsoon core and atmospheric subsidence in drylands to the north and west has been hypothesized to explain greater-than-modern aridity at the desert margin of northern China in the early Holocene (Masson et al. 2009). Our simulations show enhanced precipitation in JJA (Fig. 4b, d, f, h) and SON (not shown) in the Asian monsoon region, associated with stronger upward motion (negative vertical pressure velocity anomaly) during the early Holocene compared to PI (Fig. 9d, f). The region in mid- and high latitude Eurasia with the most significant change towards more downward motion (positive vertical pressure velocity anomaly) is over north-central Kazakhstan, where increased subsidence may be accentuating the aridity in the early Holocene during most seasons (Fig. 9c-f). In other areas of central Asia, however, there is no significant change towards more downward motion (Fig. 9c) to correspond with the significant negative anomalies of $P-E$ in the winter months (Fig. 6). The fact that dry conditions in the early Holocene seem to result mostly from changes in winter climate also provides a strong argument against a dynamic link with the summer monsoon (the "monsoon-desert hypothesis"). Figure 6 clearly shows that there is no change in summer $P-E$ between the Early Holocene and either the mid Holocene or the PI. So, the reduction in early Holocene effective moisture inferred from proxy records is unlikely to be due to changes in the summer season, regardless of whether the vertical motion (vertical pressure velocity) has changed. Changes in vertical pressure velocity at $600 \mathrm{hPa}$ between the early and mid-Holocene in central Asia are similar, but generally smaller, to those shown in Fig. 9. We conclude that subsidence has only small regional effects on effective moisture in central Asia during the Holocene.

\subsection{Effect of remnant Laurentide ice sheet and meltwater fluxes}

Including the remnant LIS and associated freshwater fluxes released into the North Atlantic reduces early Holocene warming over North America and downstream over the north Atlantic. Despite this, the changes in annual $P-E$ during the early Holocene in central Asia are not significantly different (at the $95 \%$ level) between the three $8.5 \mathrm{ka}$ BP experiments (Exp_8.5 ka, Exp_8.5ka $\mathrm{ICE}_{\mathrm{IC}}$, and Exp_8.5ka $\mathrm{keltice}_{\text {) }}$ (Fig. 6), nor are the causes for $P-E$ changes (Table 2), suggesting that the addition of the remnant Laurentide ice sheet and freshening of the North Atlantic have only a minor impact on the early Holocene drying in central Asia. Instead, orbital forcing can account for most of the signal.

\section{Summary and concluding remarks}

We presented model results from the CCSM3.0 testing the effects on early Holocene climate of orbital forcing as well as of deglaciation of the residual LIS. In arid central Asia, the model simulates decreased $P-E$ in the early Holocene compared to the middle and late Holocene, with most of the signal occurring during the winter months. Also, the simulated summer monsoon precipitation was increased during the early Holocene over south and East Asia 
Fig. 7 Pressure/height versus latitude diagrams of zonallyaveraged $\left(0^{\circ}-180^{\circ} \mathrm{E}\right)$ differences of temperature (left panel) and u-component wind (right panel) between 8.5 ka experiments and PI for December to March (DJFM) and between Exp_8.5ka MELTICE and Exp_6 ka for October to April (ONDJFMA). Contour intervals are $0.2 \mathrm{~K}$ and $0.4 \mathrm{~m} / \mathrm{s}$, respectively, with the exception of $u$ wind in the bottom row (j), which is $0.2 \mathrm{~m} / \mathrm{s}$. Stippling indicates differences that are significant at $95 \%$ level
$\mathrm{PI}$
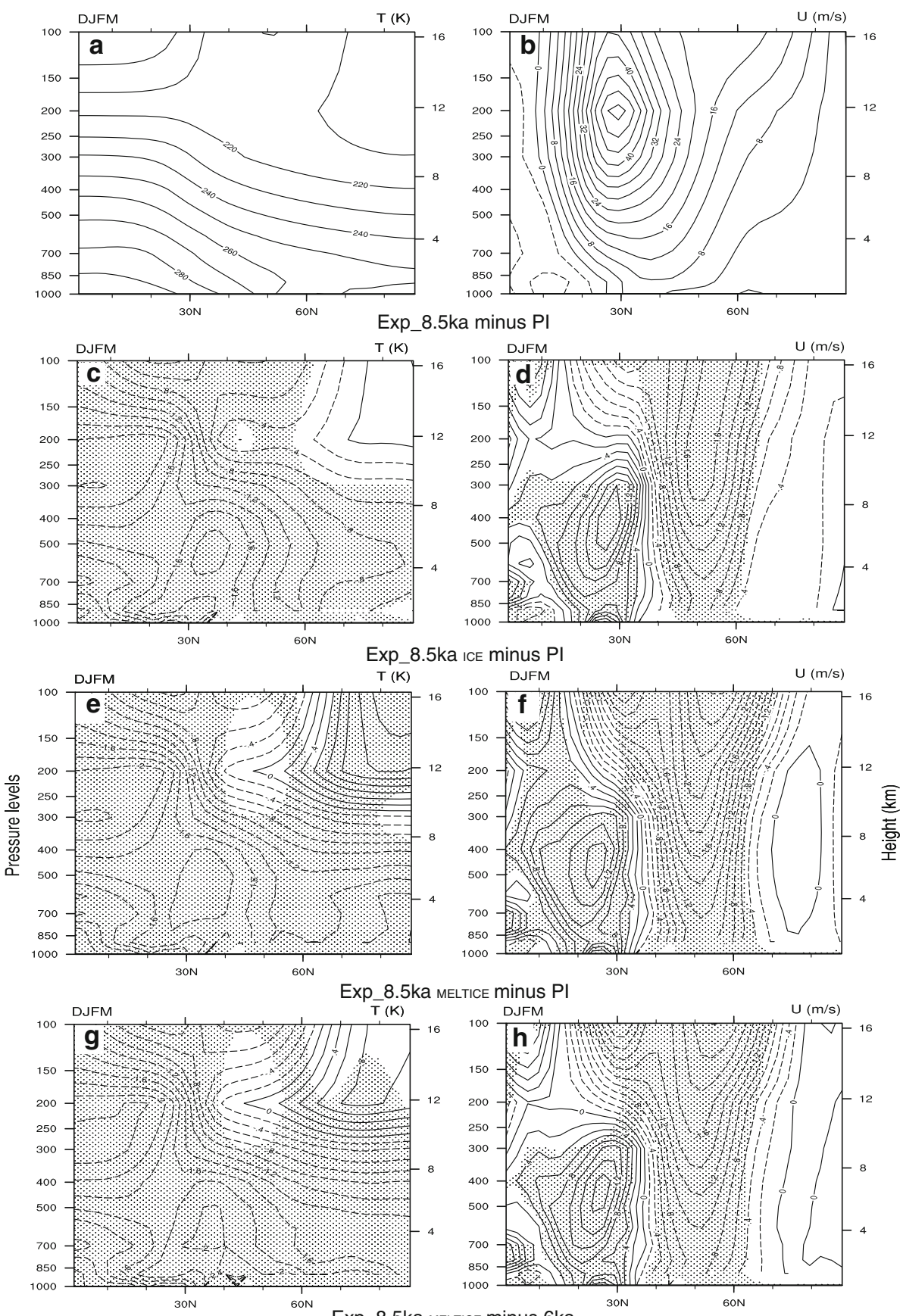

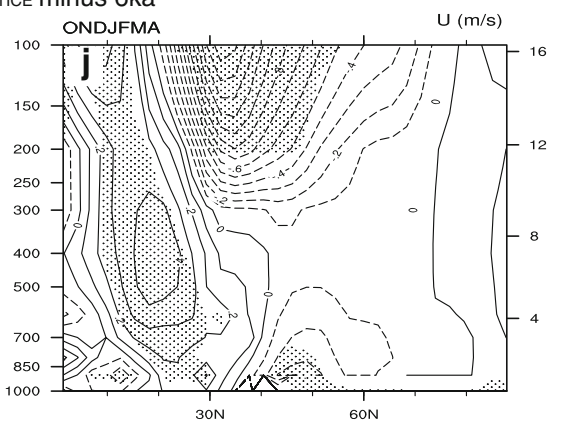


Fig. 8 Surface evaporation differences between $8.5 \mathrm{ka}$ experiments and PI for December to March (DJFM) $(\mathbf{a}-\mathbf{c})$ and between

Exp_8.5kameltice and Exp_6 ka for October to April (ONDJFMA) (d). Units: $\mathrm{mm} /$ day. Stippling indicates differences that are significant at $95 \%$ level
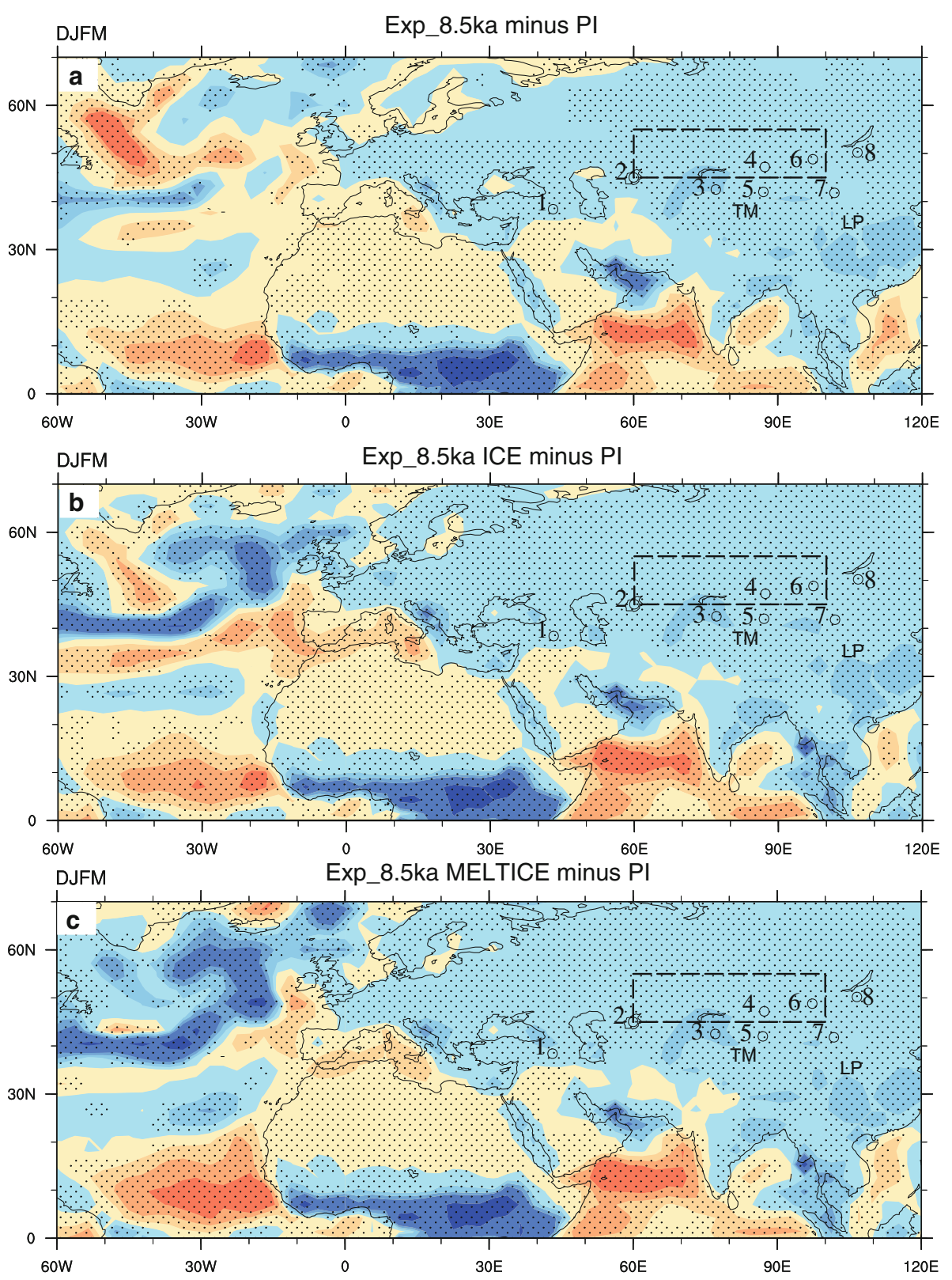

ONDJFMA Exp_8.5ka MELTICE minus Exp_6ka

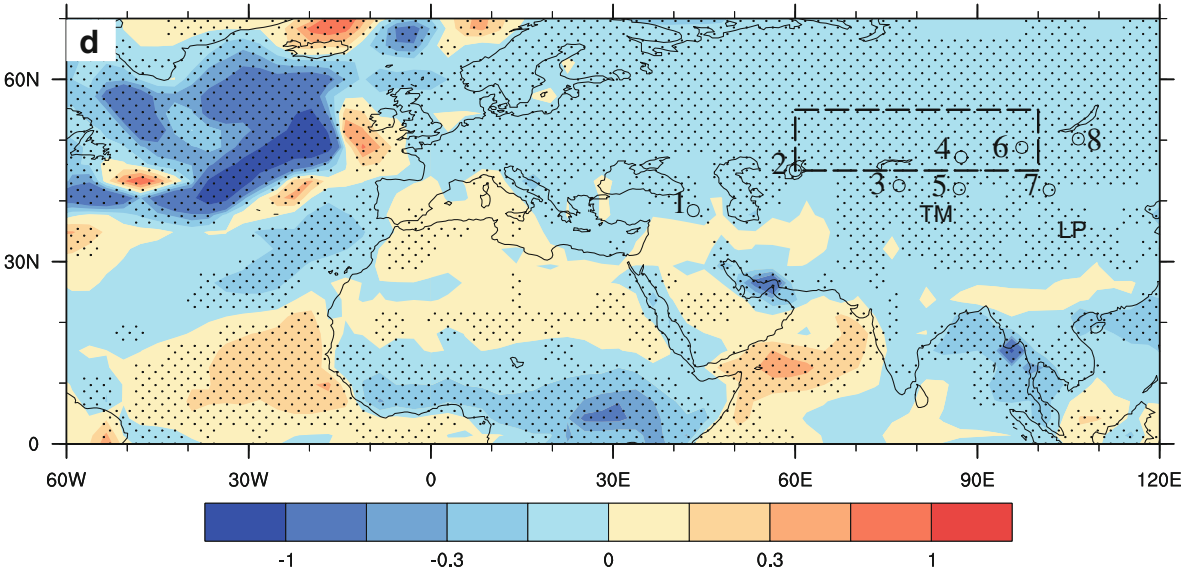



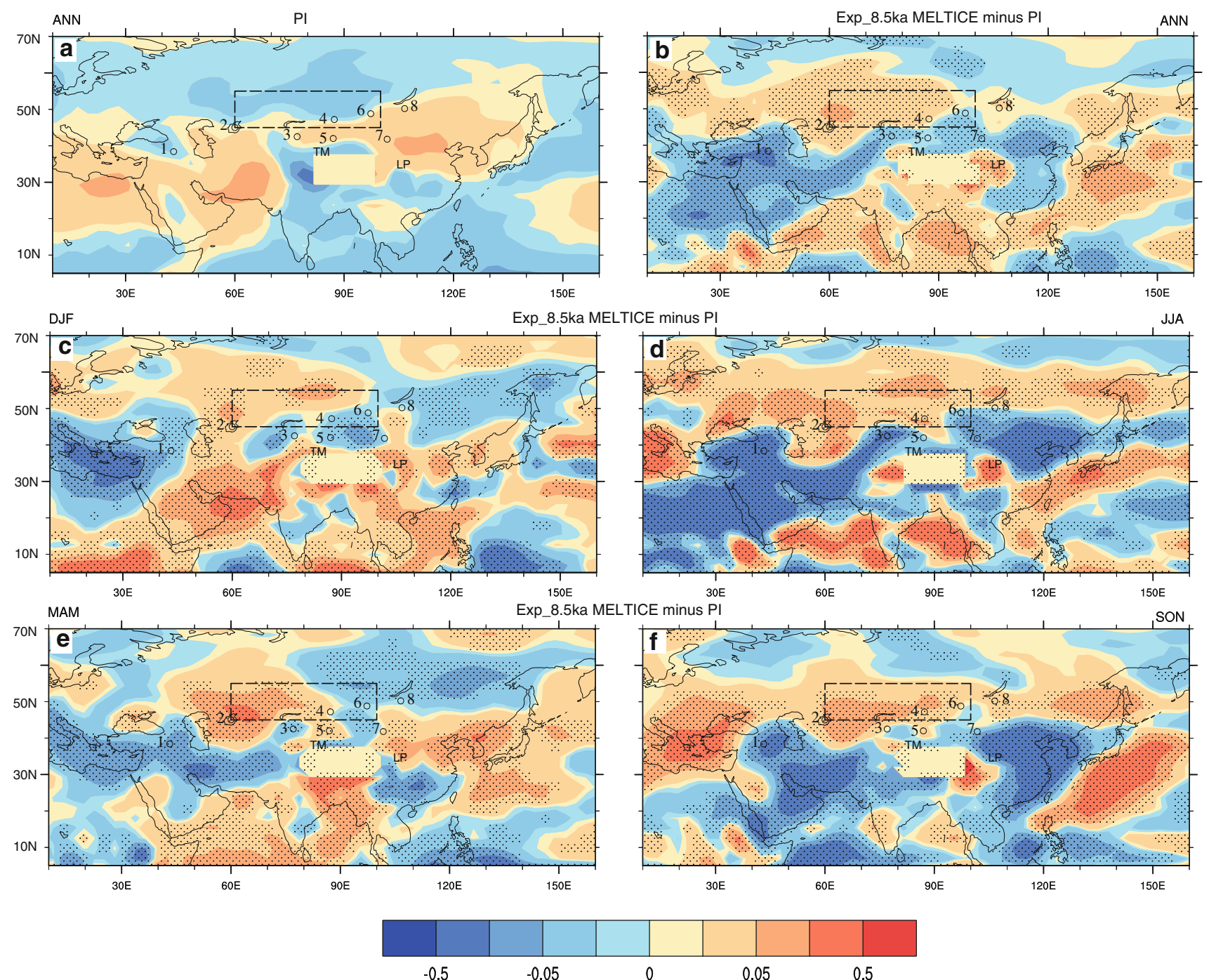

Fig. 9 Differences in vertical pressure velocity $\Omega$ at $600 \mathrm{hPa}$ (units in $\mathrm{Pa} \mathrm{s}^{-1}$ ) for the annual mean $(\mathbf{a}, \mathbf{b})$ and four seasons $(\mathbf{c}-\mathbf{f})$. Positive values $(\Omega>0)$ indicate more downward and the negative more upward motions. Annual mean $\Omega$ values in the figures are multiplied

by 10 . Stippling indicates significance at the $95 \%$ level. Grid cells on the Tibetan Plateau with elevations above $600 \mathrm{hPa}$ are not plotted in the figures

compared to $6 \mathrm{ka}$ and PI. The simulated early Holocene increase in precipitation and the intensity of the monsoon circulation over southeastern monsoonal Asia is in broad agreement with paleoclimate records and other climate model simulations (e.g., Liu et al. 2003), and decreased effective moisture in central Asia at $8.5 \mathrm{ka}$ also agrees with proxy records (e.g., Chen et al. 2008).

We attribute decreased $P-E$ in central Asia during the early Holocene to a reduction in moisture advection brought about by both a weakening of westerly winds and decreased upstream evaporation. A reduced meridional temperature gradient, forced by latitudinal differences in orbital forcing in the early Holocene compared to $6 \mathrm{ka}$ and PI, produces a marked reduction in the westerly component of the wind over Eurasian land in the $8.5 \mathrm{ka} \mathrm{BP}$ experiments, consistent

with the thermal wind relationship. At the same time, upstream evaporation from the Mediterranean, Black, and Caspian Seas was reduced in the early Holocene winter compared to the middle and late Holocene due to decreased insolation and colder temperatures. The implication is, therefore, that local hydrologic recycling was decreased in the early Holocene. The fact that dry conditions in the early Holocene seem to result mostly from changes in winter climate also provides a strong argument against a dynamic link with the summer monsoon. As an extra forcing in the early Holocene climate system, the Laurentide ice sheet has a substantial cooling effect over high latitudes, especially just over and downstream of the ice sheet, but our conclusions suggest it plays only a minor role in generating early Holocene aridity in central Asia. 
Acknowledgments This study was supported by the National Natural Science Foundation of China (NSFC) Innovation Team Project (Grant No. 40721061), the 111 Project (Grant No. B02026). L. Jin is grateful to China Scholarship Council (CSC) for providing him a scholarship during his research visit (2008-2009) at the National Center for Atmospheric Research (NCAR), USA, whose hospitality is also appreciated. The National Center for Atmospheric Research is sponsored by National Science Foundation (NSF). C. Morrill and B.L. Otto-Bliesner acknowledge grants from the NSF Office of Polar Programs for completion of the $8.5 \mathrm{ka}$ BP simulations. The authors are very much grateful to two anonymous reviewers for their helpful comments and constructive suggestions for the manuscript.

Open Access This article is distributed under the terms of the Creative Commons Attribution Noncommercial License which permits any noncommercial use, distribution, and reproduction in any medium, provided the original author(s) and source are credited.

\section{References}

Böhner J (2006) General climatic controls and topoclimatic variations in central and high Asia. Boreas 35:279-295

Briegleb BP, Bitz CM, Hunke EC, Lipscomb WH, Holland MM, Schramm JL, Moritz RE (2004) Scientific description of the sea ice component in the Community Climate System Model Version 3: NCAR Tech. Note NCAR/TN-463+STR, 70 pp

Broccoli AJ, Manabe S (1992) The effects of orography on midlatitude Northern Hemisphere dry climates. J Clim 5: $1181-1201$

Carlson AE, LeGrande AN, Oppo DW, Came RE, Schmidt GA, Anslow FS, Licciardi JM, Obbink EA (2008) Rapid early Holocene deglaciation of the Laurentide ice sheet. Nat Geosci 1:620-624

Chen FH, Yu Z, Yang M, Ito E, Wang S, Madsen DB, Huang X, Zhao Y, Sato T, Birks JB, Boomer I, Chen J, An C, Wünnemann B (2008) Holocene moisture evolution in arid central Asia and its out-of-phase relationship with Asian monsoon history. Quat Sci Rev 27:351-364

Chen GS, Kutzbach JE, Gallimore R, Liu Z (2010) Calendar effect on phase study in paleoclimate transient simulation with orbital forcing. Clim Dym. doi:10.1007/S00382-010-0944-6

Clark PU, Alley RB, Pollard D (1999) Northern Hemisphere ice-sheet influences on global climate change. Science 286:1104-1111

Collins WD, Rasch PJ, Boville BA, Hack J, McCaa JR, Williamson DL, Briegleb BP (2006) The formulation and atmospheric simulation of the community atmosphere model version 3 (CAM3). J Clim 19:2144-2161

Dahl-Jensen D, Mosegaard K, Gundestrup N, Clow GD, Johnsen SJ, Hansen AW, Balling N (1998) Past temperatures directly from the Greenland ice sheet. Science 282:268-271

Dickinson RE, Oleson KW, Bonan G, Hoffman F, Thornton P, Vertenstein M, Yang ZL, Zeng X (2006) The Community Land Model and its climate statistics as a component of the Community Climate System Model. J Clim 19(11):2302-2324

Feng ZD, An CB, Wang HB (2006) Holocene climatic and environmental changes in the arid and semi-arid areas of China: a review. Holocene 16:119-130

Fleitmann D, Burns SJ, Mudelsee M, Neff U, Kramers J, Mangini A, Matter A (2003) Holocene Forcing of the Indian Monsoon recorded in a stalagmite from Southern Oman. Science 300: 1737-1739

Fleitmann D, Burns SJ, Mangini A, Mudelsee M, Kramers J, Villa I, Neff U, Al-Subbary AA, Buettner A, Hippler D, Matter A (2007)
Holocene ITCZ and Indian monsoon dynamics recorded in stalagmites from Oman and Yemen (Socotra). Quat Sci Rev 26:170-188

Gao YX (1962) On some problems of Asian monsoon. In: Gao YX (ed) Some questions about the East Asian monsoon. Chinese Science Press, Beijing, pp 1-49 (in Chinese)

Gent PR, Bryan FO, Danabasoglu G, Lindsay K, Tsumune D, Hecht NW, Doney SC (2006) Ocean chlorofluorocarbon and heat uptake during the 20th century in the CCSM3. J Clim 19: 2366-2381

Gu ZY, Liu JQ, Yuan BY, Liu TS, Liu RM, Liu Y, Yasukawa K (1993) Monsoon variations of the Qinghai-Xizang Plateau during the last 12,000 years: Geochemical evidences from the sediments in the Siling Co (lake). Chin Sci Bull 38(7):577-581

Gupta AK, Anderson MD, Overpeck JT (2003) Abrupt changes in the Asian southern monsoon during the Holocene and their links to the North Atlantic Ocean. Nature 421:354-357

Herzschuh U (2006) Paleo-moisture evolution in monsoonal Central Asia during the last 50,000 years. Quat Sci Rev 25:163-178

Hodell DA, Brenner M, Kanfoush SL, Curtis JH, Stoner JS, Song XL, Yuan W, Whitmore TJ (1999) Paleoclimate of Southwestern China for the past 50,000 yr inferred from lake sediment records. Quat Res 52:369-380

Hong YT, Hong B, Lin QH, Shibata Y, Hirota M, Zhu YX, Leng XT, Wang Y, Wang H, Yi L (2005) Inverse phase oscillations between the East Asian and Indian Ocean summer monsoons during the last 12000 years and paleo-El Niño. Earth Planet Sci Lett 231:337-346

Huang XZ, Chen FH, Fan YX, Yang ML (2009) Dry late-glacial and early Holocene climate in arid central Asia indicated by lithological and palynological evidence from Bosten Lake, China. Quat Int 194:19-27

Kaplan MR, Wolfe AP (2006) Spatial and temporal variability of Holocene temperature in the North Atlantic region. Quat Res $65: 223-231$

Li Y, Morrill C (2010) Multiple factors causing Holocene lake level change in monsoonal and arid central Asia as identified by model experiments. Clim Dyn 35(6):1119-1132

Licciardi JM, Teller JT, Clark PU (1999) Freshwater routing by the Laurentide Ice Sheet during the last deglaciation, Mechanisms of global climate change at millennial time scales. AGU Geophys Monogr 112:177-201

Lister G, Kelts K, Chen KZ, Yu JQ, Niessen F (1991) Closed-basin lake levels and the oxygen isotope record for ostracoda since the last Pleistocene. Palaeogeogr Palaeoclimatol Palaeoecol 84:141-162

Liu Z, Otto-Bliesner B, Kutzbach J, Li L, Shields C (2003) Coupled climate simulation of the evolution of global monsoons in the Holocene. J Clim 16:2472-2490

Masson JA, Lu H, Zhou Y, Miao X, Swinehart JB, Liu Z, Goble RJ, Yi S (2009) Dune mobility and aridity at the desert margin of northern China at a time of peak monsoon strength. Geology 37(10):947-950

Mitchell TD, Jones PD (2005) An improved method of constructing a database of monthly climate observations and associated highresolution grids. Int J Clim 25:693-712

Morrill C, Overpeck JT, Cole JE (2003) A synthesis of abrupt changes in the Asian summer monsoon since the last deglaciation. Holocene 13(4):465-476

Otto-Bliesner BL, Tomas R, Brady EC, Ammann C, Kothavala Z, Glauzet G (2006) Climate sensitivity of moderate- and lowresolution versions of CCSM3 to preindustrial forcings. J Clim 19:2567-2583

Peltier WR (2004) Global glacial isostasy and the surface of the ice age earth: the ICE-5G (VM2) model and GRACE. Ann Rev Earth Planet Sci 32:111-149 
Renssen H, Seppä H, Heiri O, Roche DM, Goosse H, Fichefet T (2009) The spatial and temporal complexity of the Holocene thermal maximum. Nat Geosci 2:411-414

Roberts N, Reed JM, Leng MJ, Kuzucuoglu C, Fontugne M, Bertaux J, Woldring H, Bottema S, Black S, Hunt E, Karabiyikoglu M (2001) The tempo of Holocene climatic change in the eastern Mediterranean region: new high-resolution carater-lake sediment data from central Turkey. Holocene 11(6):721-736

Seager R, Naik N, Vecchi GA (2010) Thermodynamic and dynamic mechanisms for large-scale changes in the hydrological cycle in response to global warming. J Clim 23:4651-4668

Shao XH, Wang YJ, Cheng H, Kong XG, Wu JY, Edwards RL (2006) Long-term trend and abrupt events of the Holocene Asian monsoon inferred from a stalagmite $\delta^{18} \mathrm{O}$ record from Shennongjia in Central China. Chin Sci Bull 51:221-228

Shen J, Liu XQ, Wang SM, Matsumoto R (2005) Palaeoclimatic changes in the Qinghai Lake area during the last 18,000 years. Quat Int 136:131-140

Wang L, Sarnthein M, Erlenkeuser H, Grimalt J, Heilig S, Ivanova E, Kienast M, Pelejero C, Pflaumann U (1999) East Asian monsoon climate during the Late Pleistocene: high-resolution sediment records from the South China Sea. Mar Geol 156:245-284

Wang YJ, Cheng H, Edwards RL, He YQ, Kong XG, An ZS, Wu JY, Kelly MJ, Dykoski CA, Li XD (2005) The Holocene Asian Monsoon: links to solar changes and North Atlantic Climate. Science 308:854-857

Wick L, Lemcke G, Sturm M (2003) Evidence of Lateglacial and Holocene climatic change and human impact in eastern Anatolia: high-resolution pollen, charcoal, isotopic and geochemical records from the laminated sediments of Lake Van, Turkey. Holocene 13:665-675

Xiao JL, Xu QH, Nakamura T, Yang XL, Liang WD, Inouchi Y (2004) Holocene vegetation variation in the Daihai Lake region of north-central China: a direct indication of the Asian monsoon climatic history. Quat Sci Rev 23:1669-1679

Yuan DX, Cheng H, Edwards RL, Dykoski CA, Kelly MJ, Zhang ML, Qing JM, Lin YS, Wang YJ, Wu JY, Dorale JA, An ZS, Cai YJ (2004) Timing, duration, and transitions of the last Interglacial Asian monsoon. Science 304:575-578 